\title{
ETIKA GURU MADRASAH IBTIDAIYAH DALAM PROSES PEMBELAJARAN
}

\author{
Idhar \\ Sekolah Tinggi Ilmu Tarbiyah (STIT) Sunan Giri Bima \\ Email : idharstitbima@gemail.com
}

\begin{abstract}
Madrasah Ibtidaiyah teachers are teachers who have the responsibility of teaching in educational institutions that combine general lessons with religious lessons and in order to integrate religious and general lessons of course require professional teachers or their own expertise in carrying out the learning process. That is why the professionalism of a teacher is a reflection of a teacher's ethics, if a teacher is not professional in the learning process it means they reflect bad ethics and if a teacher displays professionally in the learning process it is a sign that they have good ethics in the learning process. Madrasa teacher ethics in learning are reflected in the activities of a teacher, how teachers are kind to students, fellow teachers, parents of students and especially teachers display attitudes and behavior in the learning process. The attitudes and behavior of teachers are reflected in designing the learning process as a sense of responsibility for the profession as teachers, parents, society and religion and being able to involve various components in the learning process and realize learning goals. In fact, there is a reciprocity between what should be and reality because there are still many teachers who are unethical towards students, fellow teachers, parents of the community and even in terms of the learning process there are deviations in the process both related to planning and teaching. in this case a teacher must have expertise and professionalism in practice.
\end{abstract}

\begin{abstract}
ABSTRAK
Guru Madrasah Ibtidaiyah yaitu guru yang memiliki tanggung jawab mengajar di lembaga pendidikan yang memadukan antara pelajaran umum dengan pelajaran agama dan dalam rangka mengintegralkan pelajaran agama dan umum tentu membutuhkan guru yang professional atau keahlian tersendiri dalam melaksanakan proses pembelajaran tersebut. Itulah sebabnya keprofesionalitas seorang guru merupakan cerminan etika seorang guru, bila seorang guru tidak professional dalam proses pembelajaran berarti mereka mencerminkan etika tidak baik dan jika seorang guru menampilkan secara professional dalam proses pembelajaran itu bertanda mereka memiliki etika baik dalam proses pembelajarannya. Etika Guru Madrasah dalam Pembelajaran tercermin dari kegiatan seorang guru bagaiman guru bersikap baik terhadap peserta didik, sesama guru, orang tua peserta didik dan terutama guru menampilkan sikap dan prilaku dalam proses pembelajaran. Sikap dan prilaku guru tercermin dalam mendesain proses pembelajaran sebagai rasa tanggungjawa terhadap profesi sebagai guru, orang tua, masyarakat dan agama serta mampu melibatkan berbagai komponen dalam proses pembelajaran dan mewujudkan tujuan pembelajaran. Pada kenyataan terjadi timbal balik antara seharus dengan kenyataan karna masih banyak kita temukan guru yang tidak beretika terhadap peserta didik, sesame guru, orang tua masyarakat dan bahkan dalam hal proses pembelajaran terdapat penyimpangan dalam prosesnya baik berkaitan dengan perencaan maupun pengajaran. pada hal seorang guru harus memiliki keahlian dan profeinalitas dalam prakteknya.
\end{abstract}

Kata Kunci : Etika, Pembelajaran, Guru Madrasah Ibtidaiyah 


\section{PENDAHULUAN}

Etika guru sangat diperlukan dalam dunia pendidikan, sebab tanpa etika seorang guru akan menimbulkan suatu proses pendidikan yang tidak sehat terhadap peserta didiknya. Guru diibaratkan sebagai pengemudi mobil, bila pengemudinya tidak bagus dalam mengendarai maka besar kemungkinan penumpang yang diangkutnya akan merasa jengkel, marah dan bahkan akan membeci dan bosan terhadap supir tersebut dan begitu juga bagi guru yang tidak punya etika, tentu peserta didiknya akan merasa bosan terhadap guru tersebut. Oleh karena itu, guru merupakan panutan dan teladan bagi peserta didik, sebab seorang guru itu disamping punya ilmu juga harus memiliki akhlak dan sikap yang terpuji.

Saya teringat ungkapan yang menyatakan guru kecing berdiri dan peserta didik kencing berlari. Artinya etika seorang guru salah satu tolak ukur sikap dan tingkah laku anak didik, bila seorang guru menampilkan etika tidak baik kepada anak maka mereka akan mengikuti apa yang dilakukan gurunya dan sebaliknya bila seorang guru punya akhlak dan etika mulia pasti anak-anak akan terpengaruh untuk mengikutinya. Jadi, seorang guru cerminan bagi anak didik bila ingin anak didiknya menjadi anak didik yang berakhlak muliah, maka jadilah guru yang punya etika yang baik sehingga anak didik bisa mencotohnya.

Berbicara tentang etika guru khusus guru Madrasah Ibtidaiyah tentu memiliki kreteria tersendiri yang harus dimiliki oleh seorang guru sebab kreteria itu sebagai syarat dianggap dan diakuinya suatu profesi seorang guru tampa kreteria tersebut secara moral seorang guru tidak dipandang sebagai guru yang baik oleh masyarakat. Jadi seharusnya kreteria seorang guru yang beretika bisa bercermin di dalam rumusan kode etik guru di Indonesia antara lain, yaitu:

1. Guru memiliki sikap dan etika yang betul-betul berbakti dan membimbing peserta didik untuk membentuk manusia Indonesia yang benar-benar berjiwa pancasila

2. Sebagai Guru semestinya memiliki rasa tanggungjawab dalam melaksanakan tugas dan kewajiban sebagai bentuk kejujuran professionalannya

3. Guru tidak miskin informasi dalam artian seorang guru harus berusaha memperoleh informasi tentang peserta didik karna informasi itu penting untuk keberlangsungan dalam proses melakukan bimbingan dan pembinaan

4. Guru harus kreatif dan inovatif sebab seorang guru harus bisa menciptakan suasana sekolah sebaik-baiknya yang menunjang berhasilnya proses belajar mengajar

5. Guru yang baik adalah guru yang mampu bekerja sama dalam memelihara hubungan baik dengan orang tua murid dan masyarakat sekitarnya untuk membina peran serta dan rasa tanggung jawab bersama terhadap pendidikan

6. Guru terlihat beretika baik tercermin baik secara pribadi maupun secara bersama-sama mengembangkan dan meningkatkan mutu dan martabat profesinya

7. Guru punya rasa tanggungjawab secara bersama-sama memilihara dan meningkatkan mutu organisasi PGRI sebagai sarana perjuangan dan mengabdian

8. Guru diamanatkan dalam melaksanakan segala kebijakan pemerintah dalam bidang pendidikan

${ }^{1}$ Mapanganro, Pemilikan Kompetensi Guru, (Makassar, Alauddin Pres 210), h. 56. 
Dari berbagai item kode etik guru itu bisa dipahami dan maknai bahwa seorang guru khusus guru madrasah harus bertanggung jawab terhadap Negara, nilai-nilai pancasila, pemerintah, masyarakat, lembaga pendidikan,peserta didik serta kode etik sebagai guru yang melaksankan tugas keprofesionalnya. Karna tanggung jawab itu merupakan harga mati yang harus dijunjung tinggi oleh seorang guru dalam menjalankan tugas sebagai pendidik, sehingga dengan berpegang teguh pada tanggung jawab itu akan melahirkan sikap dan prilaku seorang guru yang tidak mudah diombang ambing oleh nafsu, sebab seorang guru memiliki amanat yang berat yang harus dipikul dan diemban dan tentunya dengan amanat yang berat itu guru diharapkan punya sifat ikhlas dalam menjalankanya, sebab dalam ajaran Islam orang yang ikhlas dalam menjalankan amanat akan mendapatkan imbalan yang berlimpa ruah dari Allah SWT., olehnya itu jadilah guru yang ikhlas.

Etika guru madrasah Ibtidaiyah mengandung arti bahwa pekerjaan seorang guru tersebut tentu berkaitan dalam hal merubah perilaku yang betul-betul bermoral, norma dan penghormatan, sehingga guru dituntut untuk memiliki kemampuan dasar, yang diperlukan sebagai pendidik, pembimbing, dan pengajar. Jadi dapat disimpulkan bahwa etika guru akan menjunjung tinggi nilai-nilai profesionalisme da $n$ mampu menanamkan perilaku yang baik kepada anak. ${ }^{2}$

Bila diamati dan diobservasi etika guru khusus guru madrasah Ibtidaiyah sekarang sangat jauh dari harapan yang sebenar-benar guru sebagai panutan bagi anak didik di lembaga pendidikan yang mengintegralkan pendidikan umum dengan pendidikan agama, justru mereka sendiri mencerminkan sikap yang tidak baik pada mereka. Hal itu merupakan sebagai bentuk rendahnya etika guru madrasah Ibtidaiyah di Indonesia, sekalipun kita tidak mengatakan semua guru Madrash Ibtidaiyah tidak beretika, akan tetapi tidak bisa dipungkiri juga bahwa banyak guru yang etikanya masih jauh diharapkan sebagai guru yang bisa digugu dan ditiru oleh siswanya, misalnya saja banyak keliaran informasi dari media elektronik dan media cetak bahwa banyak guru yang pacaran dengan siswa dan bahkan yang lebih parah lagi ada guru yang mencabuli siswanya. Olehnya itu sungguh biadab prilaku kebinatangan oknum seorang guru itu dan seharusnya perlu kita sadari bersama bahwa perbuatan itu disamping melanggar kode etik seorang guru dan juga perbuatan itu adalah perbuatan yang tidak manusiawi apalagi yang melakukan seorang guru yang seharusnya memberi contoh.

Dari perbuatan pembelajaran tidak beretika seorang guru salah satu faktor yang akan mempengaruhi ketidak tercapainya suatu tujuan pembelajaran, karna sifat yang tidak beretika itu akan memberikan nilai negative dalam proses pembelajaran. Olehnya itu guru harus memperhatikan baik dari segi pengetahuan, keterampilan sikap dan lainya. Sebab guru itu

\footnotetext{
${ }^{2}$ Abd. Rahman Getteng, Menuju Guru Profesional Dan Beretika ( Yogyakarta, Graha Guru 2012), h.
} 22. 
merupakan profesi yang berbeda dengan profesi lain, dengan katan lain seorang guru bukan hanya sekedar memiliki ilmu akan tetapi lebih dari itu mereka mampu mengimplementasi nilai-nilai pendidikan dalam proses pembelajaran baik pada proses merencakakan, mengajar maupun diluar dari itu yaitu pada sikap dan tingkah lakunya.

Persoalan guru madrasah Ibtidaiyah sebenarnya memang tidak sesederhana yang kita bayangkan. Tetapi membutuhkan konpetensi dan kemampuan yang betul-betul disadari sebagai guru yang memiliki rasa tanggung jawab yang amanah. Membahas kompetensi guru Madrasah Ibtidaiyah pada prinsip dasarnya yaitu memetakan faktor-faktor yang menyebabkan rendahnya kompetensi guru Madrasah Ibtidaiyah. Dalam konteks pembahasan tersebut setidaknya dapat diduga bahwa terdapat penyebab rendahnya kompetensi seorang guru Khusus guru Madrasah Ibtidaiyah yaitu ketidaksesuaian disiplin ilmu dengan bidang ajar. Sebab masih banyak guru Mata pelajaran di sekolah yang mengajar mata pelajaran yang bukan bidang studi yang dipelajarinya. ${ }^{3}$ Hal ini terjadi disebabkan oleh karena persoalan kekurangan guru pada bidang studi tertentu menyebabkan terjadi penghambatan pada kemampuan seorang guru untuk melakukan suatu pembelajaran di di madrasah Ibtidaiyah. Penyebab selanjutnya yaitu masalah kualifikasi guru yang belum setara sarjana. Konsekuensinya, standar keilmuan yang dimiliki guru menjadi tidak memadai untuk mengajarkan bidang studi yang menjadi tugasnya. Bahkan tidak sedikit guru yang sarjana, namun tidak berlatar belakang sarjana pendidikan sehingga "bermasalah" dalam aspek pedagogik.

Olehnya itu, solusinya sebagai tanggung pendidik atau dengan kata lain agar tercapainya suatu tujuan pendidikan guru yang beretika dalam proses pembelajaran, maka pendidikan linier di lembaga pendidikan suatu keharusan dan bahkan kewajiba bagi calon guru atau yang berprofesi sebagai guru dan dilaksanakan sebagai bentuk mengembangkan potensi atau kemampun dalam melaksanakan tanggung jawab dalam mendidik itu, sebab guru yang mengikuti proses pendidikan yang terencana itu salah satu guru itu yang bisa dipertanggung jawabkan secara kualifikasi sebagai guru dan juga dengan proses yang baik itu akan melahirkan guru yang berprofesional dan beretika.

Guru Madrasah Ibtidaiyah merupakan faktor penting untuk terselenggaranya proses pembelajaran di sekolah MI. Tanggung jawab ini diterima oleh guru dari tiga pihak, yaitu orangtua, masyarakat, dan negara. Orangtua mempercayai guru atas keyakinan bahwa guru memberikan pendidikan dan pengajaran sesuai dengan perkembangan anak. Dalam hal ini bisa kita nyatakan bahwa seorang guru madrasah Ibtidaiyah memiliki krakteristik tersendiri dalam proses pembelajarannya, yaitu pertama seorang guru mampu membentuk peserta didik 37411621

${ }^{3}$ Baca artikel detiknews, "Mengkritisi Kompetensi Guru"selengkapnya https://news.detik.com/kolom/d- 
yang memiliki jiwa manusia Indonesia seutuhnya, dua guru memiliki kemampuan, keahlian atau keprofesionalan yang tidak diragukan dalam melaksanakan tugas sebagai guru dalam melaksanakan proses pembelajaran, tiga guru memiliki kemampuan dalam hal mencari informasi peserta didik, sebab mereka memiliki, kelurga dan lingkungan yang berbeda serta krakter yang tidak sama, empat guru menciptakan suasana pembelajaran yang kreatif, inovatif dan menyenangkan, lima guru memiliki sifat social terhadap peserta didik, masyarakat, dan lainya. Terakhir enam, seorang guru harus bisa menjaga nama baik antara sesama guru

Guru Madrasah Ibtidaiayah salah satu profesi yang memiliki tanggungjawab yang luar biasa dalam dunia pendidikan baik yang berkaitan dengan keilmuanya sebagai pengajar, pembimbing dan perencana dan juga bertanggungjawab secara kemanusian dalam hal membantu mengembangkan potensi peserta didik dan bukan hanya itu akan tetapi bertanggungjawab atas amanat orang tua, lembaga dan pemerintah. Jadi profesi guru memiliki nilai lebih dibandingkan dengan profesi lain, sebab tanpa jasa guru mustahil bisa berkembang segala aspek kehidupan karna makna guru itu pembimbing, perancang dan lainya.

Etika profesi dan kepribadian guru madrasah yaitu membahas tentang profesi dan kepribadian guru, Etika dan profesi guru ditengah perkembangan jaman, Etika publikasi mata pelajaran MI, Kontribusi guru kelas dalam pembinaan kode etik siswa sekalipun terdapat beberapa peneliti melakukan penelitian tentang Etika profesi guru madrasah, Etika dan profesi guru di tengah perkembangan jaman, etika publika mata pelajaran MI dan Kontribusi guru kelas dalam pembinaan kode etik siswa, akan tetapi beda dengan penelitian saya karna saya meneliti tentang etika guru dalam proses pembelajaran, diman saya mau melihat dari etika guru dalam proses pembelajaran baik yang berkaitan dengan krakteristik guru dalam pembelajaran serta pengaruhnya terhadap pembelajaran beretika. Dari keterbatasan penelitian yg mengkaji etika guru dalam proses pembelajaran maka sungguh penting melakukan penelitian yang bekaitan dengan Etika guru dalam proses pembelajaran sebagai rasa tanggung jawab sebagai pendidik untuk menambah pengetahuan dan referensi dalam memajukan dunia pendidikan terutama sumbangsi terhadap calon guru MI

\section{PEMBAHASAN}

\section{Etika Guru Madrasah Ibtidaiyah (MI) Dalam proses Pembelajaran}

Persoalan kata etika sebenarnya yaitu suatu ngertian yang diambil dari istilah ethos yang bermakna suatu kebiasaan seseorang dan kata ethos itu diambil dari bahasa yunani. Kebiasaan adalah nilai dari perbuatan baik dan buruk yang menjadi kebiasaan dalam kehidupan sehari-hari. Secara umu etika merupakan bagian dari ilmu pengetahuan dalam 
kepustakaan ${ }^{4}$. Kaitan dengan etika suatu nilai yang terikat pada seseorang yang mencerminkan dalam tingkah laku dan perbuatan sehari-hari. Bila seseorang berbuat buruk berarti orang itu disebut orang jahat dan sebaliknya apabila seseorang dalam kehidupannya selaluh menampilkan perbuatan dan sikap baik dalam kehidupan sehari-hari itu bertanda mereka itu memiliki etika baik. Dengan kata lain bahwa etika merupakan tolak ukur kebaikan dan keburukan seseorang.

Dalam pengertian lain, ada istilah etika khusus yang membahas dua bagian diantaranya; pertama, etika perorangan, artinya membicarakan tentang kewajiban dan berperilaku secara kemanusiaan yang bagi dirinya sendiri. Kedua, etika secara royalitas tinggi, terkait tentang kewajiban, pola pikir manusia sebagai insan yang memiliki jiwa sosial tinggi. (Priatna, 2012:110)

Dari beberapa pengertian singkat masalah etika itu bisa kita simpulkan bahwa makna etika ada yang bersifat etika pribadi sebagai rasa kemanusiaan dan kewajiban pribadi dalam prilakunya dan ada pula etika insan yang diberi kelebihan pola pikir dan memiliki jiwa social yang tinggi. Artinya, etika itu dapat dimaknai secara sempit bagi orang-orang berprilaku individual sebagai rasa kemanusiaan dan ada pula makna etika secara luas bagi mereka yang punya pola pikir dan sifat social dalam prilakunya terhadap sesama manusia

Selanjutnya, kata "guru" salah satu kata atau ungkapan yang tidak asing lagi dalam dunia pendidikan. Bahkan setiap tahun hari guru senatiasa diperingati, begitu mulianya nama guru dan wajar harus di ingat karna jasa-jasanya. Dimana seorang guru dibebani tanggung jawab mulia untuk membantu orang-orang di lingkungan pendidikan formal sebab "Guru merupakan pendidik profesional karena guru telah menerima dan memikul beban dari orang tuas untuk ikut mendidik anak-anak. Dalam hal ini orang tua harus tetap sebagai pendidik yang pertama dan utama bagi anak-anaknya. Sedangkan guru ialah tenaga profesional yang membantu orang tua untuk mendidik anak-anak pada jenjang pendidikan sekolah". (Zakiyah Darajat). ${ }^{5}$ Guru adalah guru yang tugas dan pekerjaannya selain mengajar, memberikan macam-macam ilmu pengetahuan dan keterampilan kepada anak-anak juga mendidik. Pekerjaan guru merupakan pekerjaan yang luhur dan sangat mulia, baik ditunjau dari sudut masyarakat dan negara maupun ditinjau dari sudut keagamaan. Guru sebagai pendidik ialah seorang yang berjasa besar terhadap masyarkat dan negara.

Uraian tentang guru itu dapat kita ambil benang merah bahwa guru merupakan seseorang menyandang nama guru dan memiliki kompetensi sebagai pendidik yang memiliki ilmu dan kemampuan untuk mengembangkan potensi peserta didik dalam lingkungan pendidikan formal. Karna guru bukan hanya bertanggung jawab atas profesinya sebagai guru,

${ }^{4}$ Republic Indonesia, Kamus Bahasa Indonesia Pusat Bahasa (Cet. I edisi IV: Jakarta 2008), h. 257.

${ }^{5}$ Zakiah Daradjat, Dasar-Dasar Agama Islam (Jakarta: Bulan Bitang 1996), h. 238. 
akan tetapi lebih jauh memiliki tanggungjawab terhadap orang tua, masyarakat, Negara serta agama.

Dalam kegiatan proses pembelajaran kalau kita maknai secara sepintas adalah kegiatan yang dilakukan oleh guru secara terprogram dalam desain instruksional yang menciptakan proses interaksi antara sesama peserta didik, guru dengan peserta didik dan dengan sumber belajar. Pembelajaran tidak bisa tercapai suatu tujuan bila diabaikan dari tiga komponen tersebut, yaitu guru sebagai desain pembelajaran, peserta didik penerima pelajaran dan sumber sebagai media pembelajaran. ${ }^{6}$

Pembelajaran pada hakekatnya merupakan proses interaksi antara peserta didik dengan lingkungannya, sehingga terjadi perubahan perilaku ke arah lebih baik. Selama proses pembelajaran, tugas guru yang paling utama adalah mengkondisikan lingkungan belajar agar menunjang terjadinya perubahan perilaku bagi siswa (E.Mulyasa,2003). ${ }^{7}$ Jadi, perubahan peserta didik merupakan tujuan yang perlu diperhatikan dalam proses pembelajaran Olehnya itu, cerminan dari proses pembelajaran yang baik yaitu terbentuknya suatu tujuan untuk menciptakan perubahan secara terus-menerus dalam perilaku dan pemikiran peserta didik pada suatu lingkungan belajar. Jadi, kegiatan proses pembelajaran tidak terlepas dari kegiatan belajar mengajar. Belajar adalah suatu proses yang ditandai dengan adanya perubahan pada diri seseorang. ${ }^{8}$,

Dari tiga penjelasan tentang "Etika, Guru madrasah dan Pembelajaran" di atas dapat diambil suatu kesimpulan, bahwa seorang guru merupakan pendidik yang memiliki sikap dan prilaku dalam proses pembelajaran. Sikap dan prilaku guru tercermin dalam mendesain proses pembelajaran sebagai rasa tanggungjawa terhadap profesi sebagai guru, orang tua, masyarakat dan agama serta mampu melibatkan berbagai komponen dalam proses pembelajaran dan mewujudkan tujuan pembelajaran. Komponen-Komponen Pembelajaran Berlangsungnya proses pembelajaran tidak terlepas dari komponen-komponen yang ada didalamnya, menurut Moedjiono dan Dimyati (1993:23) komponen-komponen proses belajar megajar tersebut adalah peserta didik, guru, tujuan pembelajaran, materi/isi, metode, media dan evalusi

Guru madrasah ibtidaiyah merupakan guru yang terlibat langsung dalam proses pendidikan agar dapat berjalan dengan baik, sehingga guru disebut sebagai tenaga pendidik ( Sutjipto, 1989). Seorang pendidik tercermin dalam sikap dan tindakan sebagai profesi keguruannya atau dengatan kata lain seorang guru harus memiliki etika yang sesuai dengan kode etik profesi keguruan. Dalam UUSPN No. 20 tahun 2003 BAB XI, Pasal 39 ayat 2 dikemukakan bahwa: pendidik adalah merupakan tenaga profesional yang bertugas merencanakan dan melaksanakan proses pembelajaran, menilai hasil pembelajaran,

\footnotetext{
${ }^{6}$ Maimun, Kiat Sukses Menjadi Guru Halal ( Mataram; LEPPIM 2015), h. 53.

${ }^{7}$ E. Mulyasa, Kurikulum Tingkat Satuan Pendidikan Satuan Panduan Praktis ( Bandjung; Remaja Rosdakarya, 2007) h. 13.

${ }^{8}$ Mansur, Evaluasi Pendidikan Agama (Pondok Pinang: Songo Abadi Inti, 1982), h. 1.
} 
melakukan pembimbingan dan pelatihan, serta melakukan penelitian dan pengabdian kepada masyarakat, terutama bagi pendidik pada perguruan tinggi. Sedang menurut Undang-undang No. 14 tahun 2005. Guru adalah pendidik profesional dengan tugas utama mendidik, mengajar, membimbing, mengarahkan, melatih, menilai, dan mengevaluasi peserta didik pada pendidikan anak usia dini jalur pendidikan formal, pendidikan dasar, dan pendidikan menengah. ${ }^{9}$

Dari sikap guru dalam proses pembelajaran itu mengambarkan seorang guru bertanggung jawab atas amat undang-undang sebagai pendidik yang professional yang bisa dipetanggung jawabkan baik dalam proses maupun dalam hal tujuan, karena proses dan tujuan merupakan dua sisi yang tidak boleh dikesampingkan para pendidik bila ingin mencapai suatu amanat undang-undang. Proses salah satu langkah yang menjembatani tercapainya tujuan sedangkan tujuan merupakan titik hasil dari suatu proses, sihingga wajar guru professional itu memiliki sikap yang jelas dalam menjalankan profesinya sebagai guru.

\section{Krakteristik Etika Guru Madrasah Ibtidaiyah (MI) Dalam proses pembelajaran Peserta Didik}

Bagi seorang guru, keberagaman peserta didik yang dihadapinya adalah sebuah wahana layanan profesi yang menjadi tanggung jawabnya. Karna seorang guru harus memiliki kemampuan (ability) untuk memahami keragaman potensi peserta didik, kemampuan mengintervensi perkembangan peserta didik dan kemampuan untuk menjalin informasi tentang perkembangan murid. Semua kemampuan tersebut perlu dipelajari dengan sungguh-sungguh dan sistematis, secara akademik, tidak bisa secara alamiah, dan semua harus terinternalisasi dan teraktualisasi dalam perilaku peserta didik. ${ }^{10}$

Krakter seorang guru dalam proses pembelajaran tidak gegabah dalam mengambil tindakan, melainkan mereka harus mempertimbangkan baik dari segi keragaman peserta didik yang memiliki krakteristik yang kompleks dan membutuhkan informasi dan wawasan yang luas secara akademik untuk memahami mereka, sehingga memutuskan sesuatu berdasar dan bertanggungjawab dan pada akhirnya proses pembelajaran memberikan arah positif dalam menjalankanya. Guru diyakini menempati posisi kunci dalam pendidikan. Undangundang Nomor 14 Tahun 2005 Tentang Guru dan Dosen mendefinisikan Guru atau pendidik juga merupakan sosok yang akan memberi pengaruh kepada murid atau anak didiknya. Karena itu, seorang guru atau pendidik haruslah orang yang dapat digugu dan ditiru sebagai panutan baik dari segi pribadi, ilmu dan tingkah lakunya. Adapun guru yang ideal seharusnya memiliki sejumlah kualifikasi tertentu, baik menyangkut jasmani, etika atau akhlak maupun keilmuannya. $^{11}$

\footnotetext{
${ }^{9}$ Ibid,

${ }^{10}$ Nana Sujana, Cara Belajar Santri Aktif Dalam Proses Belajar Mengajar ( Bandung; Sinar Baru Algesindo, 1996), h. 38.

${ }^{11}$ Undang-Undang Republik Indonesia Nomor 14 Tahun 2005 Tentang Guru Dan Dosen (Jakarta: Cemerlang, $\mathrm{t}$ th), h. 3 .
} 
Dengan demikian, krakter seorang guru salah satu kunci utama dalam proses pembelajaran, sebab karakter itu salah satu cerminan seorang guru sebagai pendidik yang baik bagi peserta didik, dimana peserta didik akan merasa nyaman dengan guru tersebut, misalnya ketikan peserta didik ingin bertanya atau meminta pendapat guru, maka dengan senang hati seorang guru yang luas wawasan menjawab atau menjelaskan pertanyaan peserta didik dan juga seorang guru bukan hanya mengandal pengetahuan saja, akan tetapi menampilkan sikap yang santun atau beretika baik.

Artinya seorang guru yang baik adalah guru yang kompleks dalam segala hal dalam proses pembelajaran, misal: Sebagaimana yang dikatakan Williyam Arthur Ward "guru bisa memberi tahu. Guru baik menjelaskan. Guru ulung memperagakan. Guru hebat mengilhami. Dari ungkapan itu, mengambarkan seorang guru yang memiliki krakter etika baik, misalnya guru memberi tahu dalam arti seorang guru mengajarkan ilmunya pada peserta didik, guru baik menjelaskan dalam artian seorang guru harus membimbing peserta didik, guru ulung memperagakan, dalam arti guru harus mempraktekan pada peserta didik dan guru hebat mengilhami dalam artian seorang guru harus memotivasi peserta didik.

Begitu kompleksnya keahlian seorang seorang guru dalam proses pembelajaran, sehingga dalam segala hal harus dimiliki oleh seorang guru sebagai tanda bahwa memang guru tersebut berhak mendapatkan sandang sebagai guru professional dalam bidangnya. Karna mereka disamping memiliki ilmu yang luas akan tetapi mereka dituntut untuk mampu mempraktikan ilmunya terutama yang berkaitan dengan sikap dalam proses pembelajaran baik yang berkaitan dengan perencanaan, pengajaran maupun menilai hasilnya.

Untuk lebih jelas krakter etika seorang guru dalam prose pembelajaran dapat diuraika, berikut:

1. Guru berbakti membimbing peserta didik untuk membentuk manusia Indonesia seutuhnya yang berjiwa pancasila yaitu seorang guru memiliki jiwa berbakti kepada nusa dan bangsa dalam mendidik peserta didiknya, sehingga dengan jiwa itu akan berusaha membantu peserta didik memiliki jiwa cintah tanah air yang sama

2. Guru memiliki dan melaksanakan kejujuran professional: guru memiliki kompetensi professional yang tidak diragukan dalam proses pembelajarannya

3. Guru berusaha memperoleh informasi tentang peserta didik sebagai bahan melakukan bimbingan dan pembinaan

4. Guru menciptakan suasana sekolah sebaik-baiknya yang menunjang berhasilnya proses belajar mengajar: guru harus kreatif dalam melakukan proses pembelajar

5. Guru bukan hanya sekedar berhubungan dengan guru dan peserta didik di sekolah, akan tetapi juga seorang guru harus memelihara hubungan baik dengan orang tua murid dan masyarakat sekitarnya untuk membina peran serta dan rasa tanggung jawab bersama terhadap pendidikan

6. Guru bertanggung jawab penuh terhadap profesinya sebagai guru baik secara pribadi serta bersama-sama mengembangkan dan meningkatkan mutu dan martabat profesinya 
7. Guru secara bersama-sama bertanggung jawab menjaga lembaga seperti memilihara dan meningkatkan mutu organisasi PGRI sebagai sarana perjuangan dan mengabdian Guru melaksanakan segala kebijaksanaan pemerintah dalam bidang pendidikan. ${ }^{2}$

Guru salah satu profesi yang memiliki tanggungjawab yang luar biasa dalam dunia pendidikan baik yang berkaitan dengan keilmuanya sebagai pengajar, pembimbing dan perencana dan juga bertanggungjawab secara kemanusian dalam hal membantu mengembangkan potensi peserta didik dan bukan hanya itu akan tetapi bertanggungjawab atas amanat orang tua, lembaga dan pemerintah. Jadi profesi guru memiliki nilai lebih dibandingkan dengan profesi lain, sebab tanpa jasa guru mustahil bisa berkembang segala aspek kehidupan karna makna guru itu pembimbing, perancang dan lainya.

\section{Pengaruh Etika Guru Madrasah Ibtidaiyah (MI) Dalam Proses Pembelajaran Peserta Didik}

Guru Madrasaha Ibtidaiyah (MI) salah satu guru yang mengajar di lembaga pendidikan yang mengintegrasikan mata pelajaran pesantren dengan mata pelajaran umum. Jadi disini seorang guru madrasah Ibtidaiyah (MI) dituntut untuk mampu mengimplementasikan nilai-nilai etika yang efektif dalam proses pembelajarannya karna pembelajaran itu diharapkan bisa menciptakan peserta didik yang memiliki etika yang baik pada akhirnya, misalnya dalam pembelajaran itu tercipta prinsi-prinsip etika berikut: 1) Komunitas madrasah memang seharusnya mengem-bangkan, menjunjung tinggi dan meningkatkan nilai-nilai inti etika dan kinerja sebagai landasan karakter yang baik. 2) Madrasah berusaha secara mendalam memahami makna karakter secara kompre-hensif, didalamnya mencakup berpikir, merasa, dan melakukan. 3) Madrasah salah satu lembaga yang kompleks menggunakan pen-dekatan yang komprehensif, in-tensif, dan proaktif dalam peng-embangan karakter. 4) Madrasah menciptakan membangun sebuah komunitas yang memiliki kepe-dulian yang tinggi. 5) Madrasah tidak membatasi peserta didik mengeksprikan dirinya, dalam artian madrasah menyediakan kesem-patan yang luas bagi para peserta didik untuk melakukan berbagai tin-dakan moral. 6) Madrasah harus independen dalam menyediakan kuri-kulum akademik yang bermakna dan menantang, dapat meng-hargai dan menghormati seluruh peserta didik, mengembangkan karakter mereka dan berusaha membantu mereka untuk meraih berbagai kesuksesan. 7) Madrasah memberikan motivasi dan mendorong peserta didik un-tuk memiliki motivasi diri yang kuat. 8) Madrasah adalah komunitas be-lajar etis yang senantiasa berbagi tanggung jawab. 9) Madrasah mendorong kepemimpinan bersama yang memberikan dukungan penuh terhadap gagasan pendidikan karakter da-lam jangka panjang. 10) Madrasah harus lebih leluasa melibatkan komponen yang ada, seperti melibatkan komponen keluarga dan masyarakat sebagai mitra dalam upaya

\footnotetext{
${ }^{12}$ Abd. Rahman Getteng, Menuju Guru Profesional dan Beretika ( Yogyakarta, Graha Guru 2012) h.
} 66-67. 
pembangunan ka-rakter. 11) Secara teratur, madrasah mela-kukan assessment terhadap budaya dan iklim sekolah, keberfungsian para staf sebagai pendidik ka-rakter di sekolah, dan sejauh mana peserta didik dapat mewujudkan karakter yang baik dalam kehidupan seharihari. $^{13}$

Untuk menghasilkan kinerja yang baik dan berkualitas dalam pendidikan Soedijarto berpendapat "Untuk meningkatkan kualitas pendidikan, pertama meningkatkan kualitas rekrutmen, pelatihan, kondisi sosial, dan kondisi kerja. ${ }^{14}$ guru, mereka membutuhkan pengetahuan yang tepat, keterampilan, karakter pribadi, profesionalitas dan motivasi sesuai dengan tujuan rekrutmen guru “.

Salah satu fungsi guru Madrasah Ibtidaiyah adalah mengajar dalam paradigma pembelajaran tidak sekedar memberi atau menyampaikan pelajaran kepada peserta didik, tetapi juga terkandung makna adanya proses perubahan tingkah laku peserta didik sesuai dengan tujuan yang direncanakan. Dalam pembelajaran terjadi proses pengaturan lingkungan agar peserta didik belajar. Karena itu, penguasaan materi pelajaran bukanlah akhir dari proses pembelajaran, tetapi merupakan tujuan antara untuk pembentukan tingkah laku (karakter) peserta didik yang lebih luas. Untuk mencapai tujuan ini maka metode yang berfreasi salah satu alat untuk digunakan dalam mencapai tujuan tersebut dalam artian metode atau strategi yang digunakan dalam pembelajaran tidak hanya sekedar ceramah, tetapi juga metodemetode yang lain seperti diskusi, penugasan, sosiodrama, karyawisata, dan lain-lain. ${ }^{15}$

Guru MI memimiliki nilaih lebih dalam mempengaruhi perkembangan hasil proses pembelajaran peserta didik dimana seorang guru dengan keahlian dan krakter merencana, mengajar dan membimbing dan menyesuikan dengan lingkungan agar tercapai suatu tujuan pembelajaran karna pada akhirnya proses pembelajaran yang terencana dengan baik akan menghasilkan sesuatu hasil yang memuaskan dalam proses pembelajaran.

Salah satu tolok ukur keberhasilan belajar ditandai dengan adanya perubahan terhadap peribadi seseorang yang benar-benar telah belajar adalah adanya perubahan tingkah laku, tutur kata sikap dan pergaulannya. Dengan bahasa lain bahwa Perubahan tingkah laku tersebut menyangkut baik perubahan yang bersifat pengetahuan (kognitif), keterampilan (psikomotor) maupun yang menyangkut nilai dan sikap (afektif). Belajar tidak hanya diukur dari mata pelajaran saja, tetapi juga penguasaan, kebiasaan, persepsi, kesenangan, kompetensi, penyesuaian sosial, bermacam-macam keterampilan, dan cita-cita. ${ }^{16}$

Dalam proses pembelajaran menghasilkan perubahan pada diri peserta didik tidak semudah mengebalikan telapak tangan, membutuhkan kesabaran dan bimbingan yang terarah

\footnotetext{
${ }^{13}$ Maimunah, Peran Guru Madrasah Dalam Pendidikan Islam ( Jurnal Al-Afkar Vol. 6 no. 2 2008)

${ }^{14}$ Supardi, op.cit., h.50. 48

${ }^{15}$ Maimunah, op.cit.,

${ }^{16}$ Satu Alang, Kesehatan Menta dan Terapi Islam ( Makassar; CV Berkah Utami, 2005), 50.
} 
serta terencana oleh guru, sehingga dengan sifat sabar dan merencanakan proses pembelajaran bisa kita dapatkan hasil dari tujuan pembelajaran, sekalipun hasil itu kadang tidak secepatnya kita dapatkan butuh waktu lama untuk melihat hasilnya, karna yang namanya membibing manusia butuh proses untuk bisa berubah dan memang membutuhkan waktu yang lama untuk mengetahui hasil dari bimbingan kita bahkan untuk bisa kita melihat hasil bertahu-tahun dulu bahkan lima tahun atau sepuluh tahun kedepan baru merasakan hasil dari bimbingan kita.

Oleh karena itu tugas guru dalam Mengajar menurut Nana Sudjana (2001:29) merupakan suatu proses yang berlangsung dalam proses mengatur, mengorganisasi lingkungan yang ada di sekitar peserta didik sehingga membangun kesadasaran dan motivasi peserta didik makna dan tujuan melakukan proses belajar. Jadi pembelajaran merupakan proses komunikasi dua arah, mengajar dilakukan oleh pihak guru sebagai pendidik, sedangkan belajar dilakukan oleh peserta didik atau siswa.

Jadi dalam hal ini guru MI khususnya yitu guru yang melaksanakan Proses pembelajaran. Proses pembelajaran merupakan bentuk mengimplentasikan kompetensi yang dimiliki oleh seorang guru professional karna tugas dan tanggung jawab seorang guru dalam mengarahkan peserta didik menjadi manusia yang berkualitas dalam kehidupannya esebagai bentuk manifestasi seorang pendidik yang bertanggungjawab terhadap orang tua, masyarakta dan pemerintah, jadi pekerjaan seorang guru ini sangat membutuhkan kesabaran dan keikhlasan yang tulus.

Berangkat dari pentingnya nilai etika guru dalam pendidikan khusus bagi bangsa ini, maka perlu pedoman untuk meng-implementasikannya agar menda-patkan hasil yang maksimal. Pedoman yang bisa dipertanggungjawabkan akan menumbuh kembangkan nilainilai pendidikan yang memiliki krakteristik tersendiri dalam perbuatan atau sikap kolektif. Pendidikan Madrasah, sebenar harus mewakili pedoman pendidikan krakter tersebut sebagai bentuk memahami wawasan Pendidikan Karakter dalam Islam, ( Jakarta: Kemenag, 2010), Haedar Nashir, Pendidikan Karakter Berbasis Agama artinya bahwa pendidikan krakter itu suatu keharusan seseorang mukmin dalam menjalankan dalam kehidupan baik secara pribadi maupun secara kolektif yang saling berkaitan antara satu dengan yang lainnya, sehingga menjadi satu kesatuan yang terintegrasi secara utuh. Secara sederhana, prinsip adalah suatu pernyataan fundamental atau kebenaran umum maupun individual yang dijadikan oleh seseorang atau kelompok sebagai pe-doman untuk berpikir atau bertindak.

Jadi guru MI mampu melahirkan proses pembelajaran yang berhasil sebagai salah satu perubahan perilaku yang bersifat permanen sebagai hasil dari pengalaman. Pembelajaran dapat disimpulkan sebagai suatu proses yang diatur secara baik dan benar melalui kerja sama yang utuh, terorganisir dan terkontrol atau menata sejumlah sumber potensi secara baik dan 
benar, sehingga terjadi proses pembelajaran anak yang mencapai harapan (Sudarwan Danim, 2008:34)..

Berdasarkan teori pembelajaran ada lima pengertian pembelajaran diantaranya sebagai berikut: a. Pembelajaran dimana sebagai proses transfer ilmu dan pengetahuan kepada siswa di sekolah b. Pembelajaran adalah membangun niali-nilai kebudayaan kepada generasi muda melalui lembaga sekolah c. Pembelajaran adalah kegiatan teratur serta terkontrol membangun lingkungan efektif dalam rangka untuk membangun atau menciptakan kondisi belajar bagi peserta didik d. Pembelajaran adalah upaya yang jelas menumbuhkan jiwa semangat kebangsaan peserta didik, sehingga tercipta peserta didik yang benar-benar menjadi warga masyarakat yang baik e. Pembelajaran adalah suatu proses menyediakan peserta didik untuk menghadapi kehidupan masyarakat sehari-hari (Oemar Hamalik, 1995) ${ }^{17}$.

16 Menurut Gagne sebagaimana yang telah dikemukakan oleh Nazarudin (2007:162) pembelajaran merupakan langka yang memiliki seperangkat acara terhadap peristiwa eksternal yang dirancang untuk mendukung proses belajar yang sifatnya internal. Menurut Nazarudin (2007:163) pembelajaran adalah suatu peristiwa atau situasi dan kondisi yang sengaja dirancang dalam rangka menumbuhkan serta memudahkan proses belajar dengan harapan dapat membangun kreatifitas peserta didik. ${ }^{18}$

Menurut berbagai pendapat di atas dapat disimpulkan bahwa pembelajaran adalah suatu perubahan dari peristiwa atau situasi yang dirancang sedemikian rupa dengan tujuan tersebut bisa memberikan suatu bantuan atau kemudahan dalam proses pembelajaran, sebab pembelajaran yang jelas arah tujuan akan memberikan nilai positif pada hasilnya. Jadi, peserta didik itu pada hakikatnya merupakan manusia yang berasal atau berawalkan manusia fitrah maka tergantung orang tua, lingkunganlah yang membentuknya supaya mereka menjadi manusia yang memiliki nilai kesucian sebagai manusia fitra. Sekalipun mereka fitrah bukan berarti mereka tidak dibelakali dengan perasaan akan tetapi justru dengan adanya perasaan dan pikiran itulah sehingga mereka mampu mengangkat jati diri sebagai manusia yang suci. Kemudian Mereka sebagai manusia yang dibekali dengan nafsu tentu mempunyai kebutuhan dasar yang harus dipenuhi yaitu sandang, pangan, papan, kebutuhan akan 17 rasa aman, kebutuhan untuk mendapatkan pengakuan, dan kebutuhan untuk mengaktualisasi dirinya sesuai dengan potensinya. Menurut undang undang No.20 tentang Sistem Pendidikan Nasional, peserta didik adalah bagian anggota masyarakat yang berusaha mengangkat martabat sebagai manusia melalui proses pembelajaran yang tersedia pada jalur, jenjang, dan jenis pendidikan tertentu. Peserta didik adalah subjek yang bersifat unik yang mencapai kedewasaan secara bertahap. Berdasarkan pendapat di atas dapat dikemukakan bahwa peserta

${ }^{17}$ Muhibbin Syah, Psikologi Pendidikan Dengan Pendekatan Baru ( Bandung; Remaja Rosdakarya, 2013), h. 12 . 
didik adalah seseorang dengan segala potensi yang ada pada dirinya untuk senantiasa dikembangkan baik melalui proses pembelajaran maupun ketika ia berinteraksi dengan segala sesuatu.

\section{KESIMPULAN}

Etika Guru Madrasah Ibtidaiyah dalam proses pembelajaran salah satu tugas dan tanggungjawab seorang guru dalam membangun etika belajar sebagai profesi keguruan , tergambar dan terlaksanak dalam keprofesionalitasnya dalam merencakan, membimbing dan menghasilkan nilai-nilai pembelajaran sebagai rasa tanggungjawab seorang guru terhadap profesinya sebagai guru serta tanggungjawab terhadap masyarakat, orang tua dan pemerintah.

Krakteristik guru dalam proses pembelajara terdapat pada guru sebagai payung peserta didik dalam mengajar, membina dan mendidik peserta didik untuk memahami apa yang di ajarkan serta dapat diimplementasikan dalam kehidupan nyata atau dengan kata lain guru merupakan seorang yang memiliki ilmu pengetahuan dan rasa tanggungjawab yang tinggi. Ilmu dan sifat seorang guru tersebut bisa dimiliki oleh seorang guru melalului proses pendidikan diperguruan tinggi, belajar dari pengalaman dan latihan yang sungguh-sunggun, sehingga tercipta jiwa pendidik yang memiliki krakteristik yang bisa dipertanggung jawabkan dalam nilai-nilai proses pembelajaran peserta didik

Kemudian pengaruh etika dalam proses pembelajaran itu bisa kita lihat dari hasil belajar, karna pembelajaran bukan hanya guru mentransferkan ilmu saja akan tetapi ada sesuatu hal yang harus di terima peserta didik sebagai bentuk berhasilnya proses pembelajaran. Misalnya, ketika seoran guru Madrasah Ibtidaiyah mengajarkan tentang mata pelajaran akidah pada peserta didik, bukan hanya sekedar peserta didik memahami tentang rukun Iman atau rukun Islam akan tetapi lebih dari itu bahwa peserta didik betul-betul dapat dilihat dari sikap dan tingkah lakunya, baik yang berhubungan tingkah laku kepada Allah swt, melalui shalat, zakat, puasa dll maupun tingkah laku sesama peserta didik melalui pergaulan yang baik, membantu antara sesasamanya. 


\section{DAFTAR KEPUSTAKAAN}

Abd. Rahman Getteng, Menuju Guru Profesional Dan Beretika Yogyakarta, Graha Guru 2012

Abd. Rahman Getteng, Menuju Guru Profesional dan Beretika Yogyakarta, Graha Guru 2012

Afnibar, Memahami Profesi dan Kinerja Guru, Jakarta: The Minangkabau Foundation, 2005

Baca artikel detiknews, "Mengkritisi Kompetens

Guru"selengkapnya https://news.detik.com/kolom/d-3741162/

E. Mulyasa, Kurikulum Tingkat Satuan Pendidikan Satuan Panduan Praktis Bandung; Remaja Rosdakarya, 2007

Maimun, Kiat Sukses Menjadi Guru Halal Mataram; LEPPIM 2015

Maimunah, Peran Guru Madrasah Dalam Pendidikan Islam Jurnal Al-Afkar Vol. 6 no. 22008

Mansur, Evaluasi Pendidikan Agama Pondok Pinang: Songo Abadi Inti, 1982

Mapanganro, Pemilikan Kompetensi Guru, (Makassar, Alauddin Pres 210

Muhibbin Syah, Psikologi Pendidikan Dengan Pendekatan Baru Bandung; Remaja Rosdakarya, 2013

Mulyasa, E. Menjadi Guru Profesional. Cet. Ke-9. Bandung: PT Remaja Rosdakarya, 2010.

Nana Sujana, Cara Belajar Santri Aktif Dalam Proses Belajar Mengajar Bandung; Sinar Baru Algesindo, 1996

Nasution, Harun. Falsafat dan Mistisisme dalam Islam. Cet. 7. Jakarta: Bulan Bintang, 1990.

Republic Indonesia, Kamus Bahasa Indonesia Pusat Bahasa Cet. I edisi IV: Jakarta 2008

Satu Alang, Kesehatan Menta dan Terapi Islam Makassar; CV Berkah Utami, 2005

Siddik, Dja'far. Konsep Dasar Ilmu Pendidikan Islam. Bandung: Cita Pustaka Media, 2006.

Undang-Undang Republik Indonesia Nomor 14 Tahun 2005 Tentang Guru Dan Dosen Jakarta: Cemerlang, $\mathrm{t}$ th

Uno, Hamzah B. Profesi Kependidikan. Cet. 4. Jakarta: Bumi Aksara, 2009.

Zakiah Daradjat, Dasar-Dasar Agama Islam Jakarta: Bulan Bitang 1996238. 